\title{
SYNTHETIC DIAGNOSTICS OF THE JET SYSTEM OF THE JET-2 UNMANNED DRONE
}

\author{
SYNTETYCZNA DIAGNOSTKA SYSTEMU \\ ODRZUTOWEGO BEZZALOGOWEGO STATKU \\ POWIETRZNEGO JET - 2
}

\author{
Ryszard Sabak \\ Air Force Institute of Technology \\ ryszard.sabak@itwl.pl
}

\begin{abstract}
In recent years, newer and newer designs of unmanned air vehicles have been appeared and in a spread and spread area.That is why, their service and in particular their diagnostics should be carried out both before and in each flight. In this paper, a description of both unmanned air vehicle JET-2 and its units and control system are presented. The paper includes also description of signals which are transmitted in a real time from the dron to the flight control station. These signals enable to state whether the vehicle works in a correct way. An interactive diagnostics model is presented as two united equations of state which are based on an observation that the usable value of the UAV resulting from its working standards, depends on its technical condition and what is more, technical condition depends on its working condition (intensity of usage). It should be stated that technical conditions are an environment for working conditions and working conditions are an environments for technical conditions. Presented model gives a comprehensive information about technical and working capability of a vehicle. It enables to plan next flights taking into account their currant potential and capability.
\end{abstract}

Keywords: Diagnostics, unmanned drone, ground operator of a drone

Streszczenie: Ze wzgledu na poszerzanie sie obszaru wykorzystania bezpilotowych statków powietrznych ich obstugiwanie, a w tym szczególnie diagnostyka powinna być realizowana przed $i$ w trakcie wykonywania każdego lotu. $W$ artykule przedstawiono opis bezzałogowego statku powietrznego JET-2, jego zespołów oraz układu sterowania. Przedstawiono rejestrowane i przesytane, $w$ czasie rzeczywistym, z samolotu do stacji kierowania sygnaly diagnostyczne stużace do określenia prawidlowej jego pracy. Przedstawiono model systemu diagnostycznego jako sprzęgnięte ze soba dwa równania stanu, które bazuja na spostrzeżeniu, że wartość użytkowa BSP, wynikająca z jakości jego funkcjonowania, zależy od jego stanu technicznego $i$ że stan techniczny zależy od stanu działania (intensywności użytkowania). Należy więc powiedzieć, że stan techniczny jest otoczeniem dla stanu działania, a stan działania jest otoczeniem dla stanu technicznego. Przedstawiony model daje całościowa informacje o potencjale technicznym i potencjale funkcjonalnym samolotu. Pozwala on planować następne loty z uwzględnieniem ich aktualnego potencjału, ich aktualnych możliwości.

Stowa kluczowe: Diagnostyka, bezzałogowy statek powietrzny, operator naziemny statku powietrznego 
Synthetic diagnostics of the jet system of the JET-2 unmanned drone.

Syntetyczna diagnostka systemu odrzutowego bezzalogowego statku powietrznego JET-2.

\section{Introduction}

In recent years, with the emergence of newer and newer designs of unmanned air vehicles, we have also been observing broadening of their area of use. Currently, the UAVs are constructed primarily for the army, but also for the specialized needs of surveyors, foresters, or film-makers. Their such wide application also implies the possibility of tragic consequences. Therefore, their service, including, in particular, the diagnosis of unmanned drones should be conducted before and during each flight, directly on the drone's board [2,4].

\section{Description of the JET-2 unmanned drone}

The JET-2 drone is an unmanned jet powered target of the first class according to NATO, or of the Close Range class according to the classification adopted by the Polish Armed Forces. The JET-2 drone is a jet powered air target with a programmable flight route (Fig. 1), which, at the time of research, achieved the following performance:

- maximum flight speed $\quad 150 \mathrm{~m} / \mathrm{s}$,

- ceiling $2000 \mathrm{~m}$,

- rate of climb $4 \mathrm{~m} / \mathrm{s}$,

- flight time 30 minutes,

- operating range $\quad 30 \mathrm{~km}$ away from a ground control station.

The JET-2 drone is a mid-wing monoplane of the composite structure, with a Ttype tail ballast. The drone's drive system consists of two engines $2 \times 14$ daN. The drone starts from the launcher. The technical data of the drone:

$\begin{array}{ll}\text { - length } & 3515 \mathrm{~mm} \\ \text { - wingspan } & 2850 \mathrm{~mm} \\ \text { - weight } & 90 \mathrm{~kg}\end{array}$

The main systems of the drone are:

- a spatial orientation system - AHRS, which provides information on the angular velocities, accelerations, the magnetic field intensity components in each of the three axes, and calculates the angles of spatial orientation on the basis of the above values and air speed data supplied from the aerometric sensor,

- the set of static and dynamic pressure sensors of ranges relevant to carry out flights at a speed of $150 \mathrm{~m} / \mathrm{s}$ and a maximum altitude of $5000 \mathrm{~m}$,

- a satellite-based navigation system (GPS) that provides information about the position of the air vehicle in relation to the earth and other navigation data,

- a recorder with the operating system allowing to save and load data on the nonvolatile memory in the form of a CF card with support for 16-bit file system, 
- a parallel entry-exit system that allows to read information from the $\mathrm{RC}$ receiver of the ground apparatus and enables to control servomechanisms of the control surfaces and the rescue system of the drone,

- a serial transmission system - a radio modem - ensuring communication with the ground station and handling other on-board devices communicating via a serial bus (RS232),

- power supply in the form of a direct current converter that works with a range of input voltages in the range from $9 \mathrm{~V}$ to $20 \mathrm{~V}$,

- electric fuel pumps,

- two engines of a thrust of 14 daN

- a set of 7 servomechanisms

- motor control cubicles

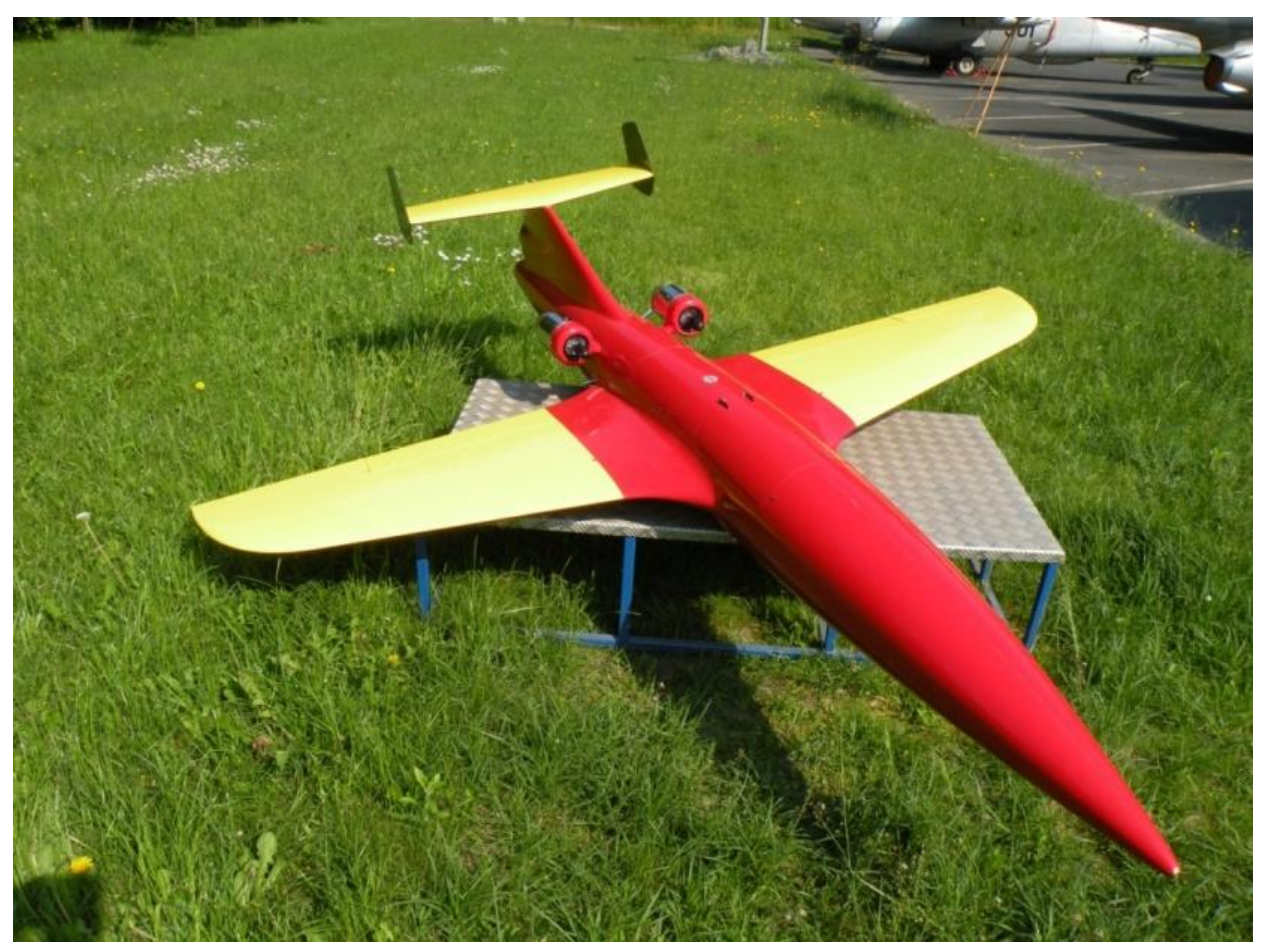

Fig. 1 The JET - 2 drone

\section{Description of the UAV's control system}

The JET - 2 unmanned drone is controlled:

- with the autopilot mounted on the board,

- manually from the flight control ground station via telecommunication lines (Fig. 2). 
Synthetic diagnostics of the jet system of the JET-2 unmanned drone.

Syntetyczna diagnostka systemu odrzutowego bezzalogowego statku powietrznego JET-2.

The automatic control system controls the twin-engine unmanned drone moving at a speed up to $150 \mathrm{~m} / \mathrm{s}$ without the pilot. The autopilot ensures stabilisation of the object in all three axes and allows to fly along set turning points of the route. In addition, the design of the autopilot was designed with a view of an automatic start from the launcher and automatic approach to the landing zone.

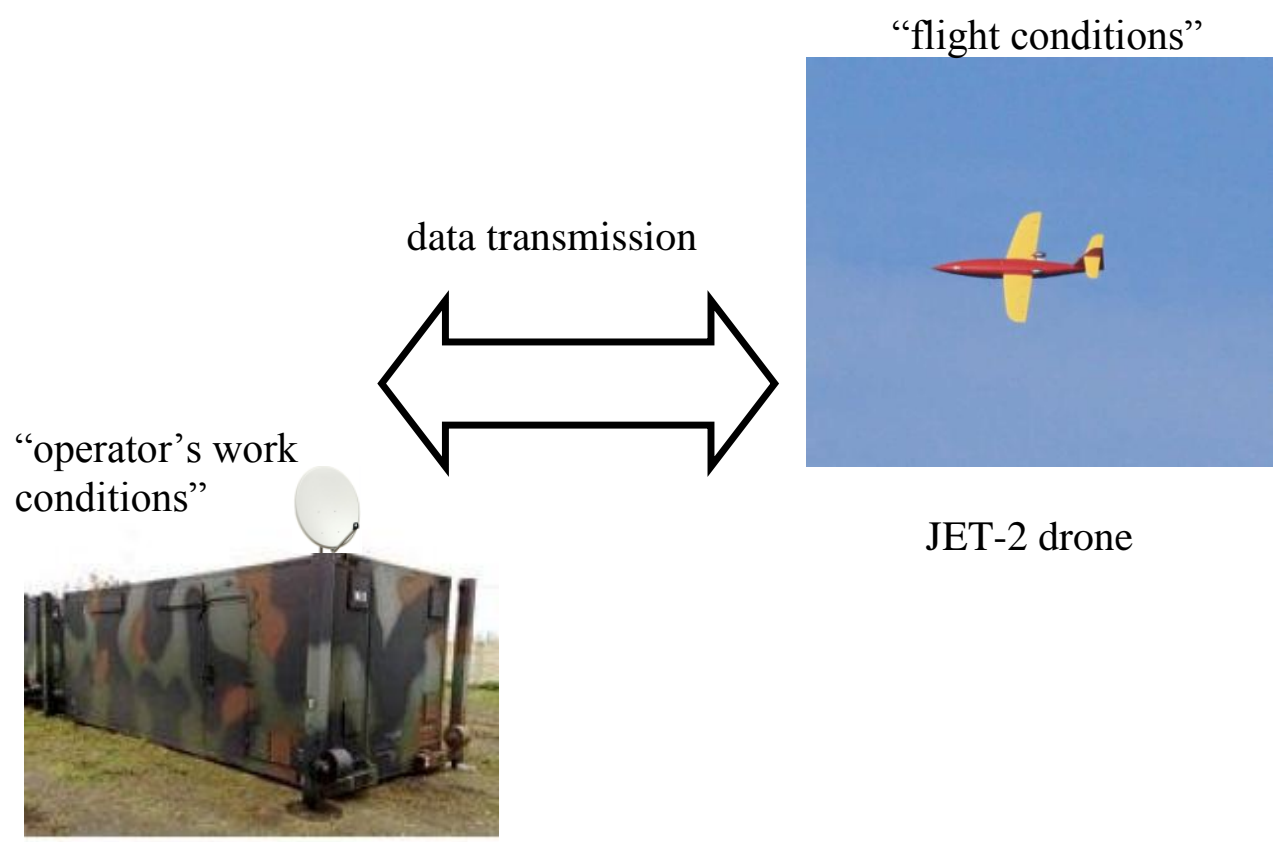

ground control station

Fig. 2 The data transmission from the ground station to the drone

\section{Complex diagnostics of the JET-2 drone}

The increasing use of the unmanned drones implies the possibility of tragic consequences. Therefore, testing, in particular the diagnosis of unmanned drones should be conducted already during the flight, directly on the drone's board. Fig. 3 shows the block diagram of the drone's control system.

Components' work parameters are sent to the control station with the radio modem. They are used to determine the correctness of the operation accomplishment that is to determine the functional state of the drone $-a_{D}(\theta)-$ and its condition $a_{T}(\theta)$. The functional state and condition can be determined on the basis of:

- usage conditions (environmental signals) - U

- diagnostic signals - D 
Ryszard Sabak

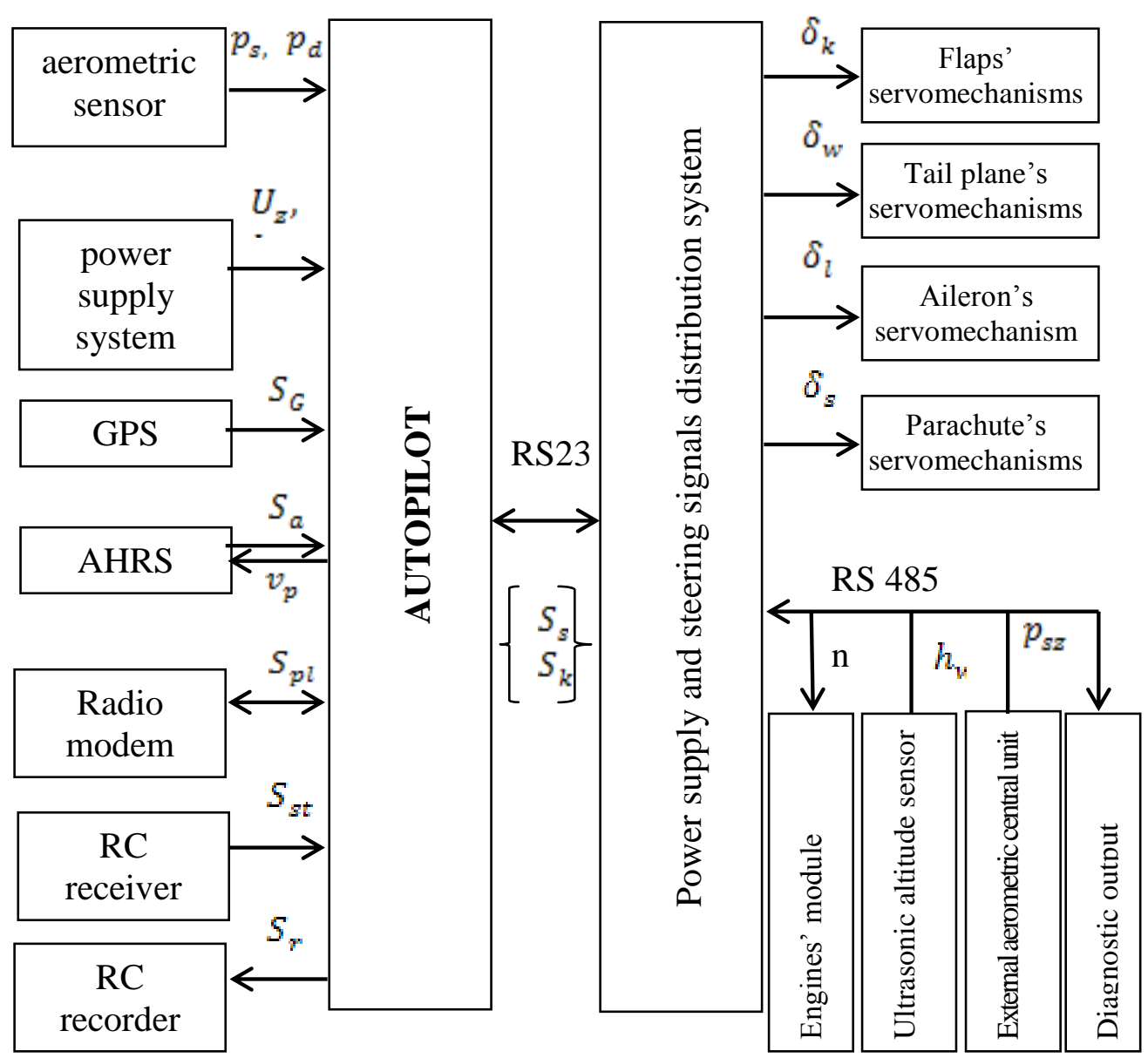

Fig. 3 The block diagram of the JET - 2 drone's control system

where: $S_{S}$ - set of steering signals

$S_{k}$ - set of control signals

$S_{G}$ - set of signals from the GPS about the position of the drone in the space and the flight speed

$S_{a}$ - set of signals from the AHRS (angles, speeds, and accelerations)

$S_{p l}$ - set of flight parameters signals from the radio modem

$S_{s t}$ - set of signals from the control station

$S_{r} \quad$ - set of registered signals (51 signals)

A relationship between environmental and diagnostic signals can be described with an interactive model.

The interactive model of the unmanned drone consists of two equations of state coupled together, based on the observation that the use (action) value of the UAV, resulting from its quality of operation, depends on its technical condition, resulting 
Synthetic diagnostics of the jet system of the JET-2 unmanned drone.

Syntetyczna diagnostka systemu odrzutowego bezzalogowego statku powietrznego JET-2.

from wear and tear, and that the technical condition (its quick change) depends on the operating condition (use intensity). Therefore, it must be said that the technical condition is the environment for the operating condition, and the operating condition is the environment for the technical condition, which can be written in the form of two coupled equations of state $[1,3,6]$ :

$$
\begin{aligned}
& \frac{d U}{d \theta}=a_{D} U+b_{D} D \\
& \frac{d D}{d \theta}=a_{T} D+b_{T} U
\end{aligned}
$$

where:

$\mathrm{U}$ - complex use signal associated with the operating condition (of the drone and the operator);

D - complex diagnostic signal associated with the technical condition;

$a_{D}$ - operating condition parameter;

$b_{D}$ - parameter of intensity of the impact of the technical condition on the UAV's action;

$a_{T}$ - the UAV technical condition parameter;

$b_{T}$ - parameter of intensity of the impact of the operating condition on the UAV's wear and tear.

Use (environmental) signals of the unmanned drone are:

- actual course

- actual flight altitude

- actual flight speed

- flight conditions

- "quality" of the operator's work.

During the drone's flight, on the on-board recorder, 64 diagnostic signals are saved, of which 51 are sent to the flight control station in real time. They are used to determine the current position of the drone in the air and to determine the proper work of:

a) power systems,

- voltage and momentary current consumption in the engine installation

- voltage and momentary current consumption in the autopilot installation

- voltage in the servos installation

- voltage in the fuel pump of the engine

- total power consumption from the engine battery pack

- total power consumption from the airborne battery pack 
b) the drive system,

- rotational speed of engines

- engines' exhaust gases temperatures

- total fuel consumption

c) the autopilot,

- the set and actual flight course

- the set and actual flight altitude

- the set and actual flight speed

- the set and actual flight route parameters

All the presented above signals can be put down to a dimensionless and homogeneous form $[3,5,6]$.

During the preparation of the drone for the flight, the diagnostics of the parameters of the estimated flight route takes place. Sent and saved parameters are compared with the capabilities and technical limitations of the drone. One example of the restrictions applied on the drone concerns the estimated flight route. It may happen that the sent geographic coordinates of the point deviate from the drone's capabilities. Therefore, the drone compares basic parameters of the flight route with the restrictions entered earlier and sends an error message $[4,5]$.

In addition, the complex parametric diagnostics of the drone is conducted. $a_{D}$ and $\mathrm{a}_{\mathrm{T}}$ parameters of equation [1] and [2] show comprehensive information about the technical and functional potential of the drone. It allows to plan the next flights taking into account their current potential and capabilities $[2,3,6]$.

\section{Conclusions}

The system of the unmanned drone consisting of the drone and the control station is a complex diagnostic system. For diagnostic purposes, there is a need for recording, sending, and evaluation of over 60 drone's signals, as well as the presence of the operator. The signals can be used to diagnose individual systems of the drone. They can also be used synthetically for evaluation of its technical and functional potential. This will allow to plan the drone's flights in accordance with its current capabilities.

\section{Bibliography:}

[1]Cempel Cz. 2006, „Teoria i inżynieria systemów”, ITE-PIB Radom [System theory and engineering]

[2]Dąbrowski T., Będkowski L. 2010, „Diagnozowanie i dozorowanie stanu obiektu eksploatacji”, Instytut Technologii Eksploatacji - Problemy Eksploatacji 2, str. 7-15 [Diagnosing and control of the operation object condition] 
Synthetic diagnostics of the jet system of the JET-2 unmanned drone.

Syntetyczna diagnostka systemu odrzutowego bezzalogowego statku powietrznego JET-2.

[3] Grądzki R., Lindstedt P. 2015, „Method assessment of technical object aptitude in environment of exploitation and service conditions", Eksploatacja i Niezawodność - Maintenance and reliability vol. 17 no 1/2015, pp . $54-63$.

[4]Lewitowicz J. 2010, „Ryzyko w eksploatacji statków powietrznych”, Instytut Technologii Eksploatacji - Problemy Eksploatacji 2, str. 43-48 [Risks in aircraft operation]

[5]Lindstedt P. 2009, „The Method of Complex Worthiness Assessment of Engineering Object in the Process of its Use and Service", Solid State Phenomena vol.144, pp 45-52.

[6]Lindstedt P., Majewski P. 2010, "The comprehensive method for availability monitoring of antifriction bearings during the lifetime period", Journal of KONBiN, No. 4 (16), str. $25-36$.

The research was conducted within the framework of the project No. O ROB 0065 03001 "Jet air targets with a programmed trajectory" (Polish: "Odrzutowe cele powietrzne z programowana trasa lotu") funded by the National Centre for Research and Development in Poland.

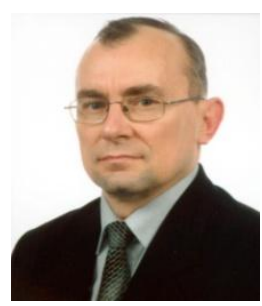

Ph.D. Ryszard Sabak, Air Force Institute of Technology, Warszawa, lecturer, specialisation: machinery building, UAV's military engineering, research and development,management. Publications in field. 